\title{
Corporate Nonfinancial Disclosure Practices and Financial Analyst Forecast Ability Across Three European Countries*
}

\author{
Ann Vanstraelen \\ Universiteit Antwerpen and Universiteit Maastricht
}

\author{
Marilyn T. Zarzeski \\ University of Mississippi
}

Sean W.G. Robb

University of Toronto

\begin{abstract}
This paper presents evidence that companies across three continental European countries (Belgium, Germany and the Netherlands) provide varying degrees of analyst recommended nonfinancial disclosures to the marketplace. This study is the first to examine the relationship of Jenkins Committee nonfinancial disclosure levels with the accuracy and dispersion of financial analysts' earnings forecasts. Seemingly unrelated regression tests show that larger companies and companies with a global focus voluntarily provide higher levels of both forward looking and historical nonfinancial disclosures. Additionally, higher levels of forward looking nonfinancial disclosures are associated with lower dispersion and higher accuracy in financial analysts' earnings forecasts.
\end{abstract}

\section{Introduction}

In this paper, we identify factors that affect nonfinancial disclosure choices of firms in Belgium, Germany, and the Netherlands. We then examine the relationship of Jenkins Committee nonfinancial disclosure levels with the accuracy and dispersion of financial analysts' earnings forecasts for firms in these three countries. Our two main objectives are: (1) to improve our

\footnotetext{
*We thank Ole-Kristian Hope, Robert Knechel, Theresa Libby, Robert Mathieu, Erik Peek, Ping Zhang, workshop participants at the University of Toronto and participants at the 2001 and 2002 European Accounting Association Annual Congress, the 2002 American Accounting Association International Section Mid-Year Meeting and the 2002 IAAER/HKAAA World Congress of Accounting Educators for helpful comments. We also gratefully acknowledge I/B/E/S International Inc. for providing earnings per share forecast data, available through the Institutional Brokers' Estimate System and made available as part of a broad academic program to encourage earnings expectation research.

Correspondence to: Dr. Ann Vanstraelen. Faculty of Applied Economics UFSIA-RUCA, Prinsstraat 13, B-2000 Antwerp, Belgium, Email: ann.vanstraelen@ua.ac.be
} 
understanding of the factors that determine companies' voluntary nonfinancial disclosure choices in three European Union (EU) neighbouring countries and, (2) to determine the extent to which voluntary nonfinancial disclosures affect the accuracy and dispersion of financial analysts' earnings forecasts. This study builds upon prior work by Robb et al. (2001) dealing with voluntary nonfinancial disclosure choices of firms across three Anglo-American countries. In contrast, our paper focuses on three continental European countries that differ in terms of legal and institutional setting, financial accounting practices and culture. An additional contribution of this study is that it is the first to examine the relationship of Jenkins Committee nonfinancial disclosure levels with the accuracy and dispersion of financial analysts' earnings forecasts in an international setting.

We begin by determining the extent to which our sample companies, in each country, disclose nonfinancial information as recommended by financial analysts to the Jenkins Committee. Specifically, we examine the relationship between voluntary nonfinancial disclosure practices and the following firm characteristics: industry classification, country of domicile, geographic dispersion, cross-listings, company size, and compliance with International Accounting Standards (IASs). We then examine the relationship of voluntary nonfinancial disclosure levels to analysts' earnings forecast accuracy and dispersion.

Our results show that across our sample firms, there are statistically significant differences in disclosure levels for the various nonfinancial information categories identified in the Jenkins report. Factors such as firm size, industry classification, degree of geographic dispersion, crosslistings on foreign stock exchanges, and country of domicile help to explain these differences. Furthermore, we demonstrate that the disclosure of forward-looking nonfinancial information is associated with significantly lower dispersion levels and higher accuracy of analysts' earnings forecasts. On the other hand, disclosure of historical nonfinancial information does not affect either the dispersion or accuracy of analysts' earnings forecasts in a statistically significant manner.

Identifying the factors that encourage corporate nonfinancial disclosures may be useful to standard setters in their harmonization deliberations. In addition, examining the relationship of nonfinancial disclosure levels with the accuracy and dispersion of financial analysts' earnings forecasts may improve our understanding of how analysts generally form their expectations and the specific role different types of nonfinancial disclosures play in the formation of those expectations. 
The next section of the paper discusses the related theory and the relevant literature. Section 3 describes the model and our hypotheses. In section 4 we describe the data we employ. Sections 5 and 6 present our results and conclusions respectively.

\section{Theory}

\subsection{Nonfinancial Disclosures}

Prior literature suggests that there are benefits to capital markets from firms voluntarily disclosing information. For example, increased disclosure reduces the cost of capital (Barry and Brown, 1984, 1985, 1986; Easley and O'Hara, 2000), increases liquidity (Diamond and Verrecchia, 1991; Kim and Verrecchia, 1994), and increases information intermediation (Diamond, 1985; Bhushan, 1989; Lang and Lundhom, 1996). In general, the empirical literature supports the existence of these benefits (see Healy and Palepu, 2001). In the absence of disclosure costs or uncertainty about the existence of information, the theoretical literature suggests that firms should follow a full disclosure policy (Jovanovic, 1982; Verrecchia, 1983). The theory essentially is that when a price-maximizing manager withholds information from the market, investors become suspicious about the quality of the investment and they discount its quality to the point where the manager is always better off with a full disclosure policy. However, in an international setting, it is not clear what influence, if any, cross-country factors may have on voluntary disclosures of nonfinancial information.

Prior research documents that there is substantial variation in firms' financial reporting practices across nations (Hope, 2003). The level of required disclosure is known to affect firms' levels of voluntary disclosure. This variation in firms' financial reporting contributes to differential information flows that can affect the allocation of resources (SEC, 2000). To the extent that investors' investment decisions are dependent on having adequate information regarding the efficiency with which assets are employed by the firm, any variation in firms' financial reporting practices across national borders can dramatically affect the allocation of resources across capital markets.

There is evidence that the extent of financial disclosure varies among firms with respect to firm size (Healy and Palepu, 1994), industry, and listings on foreign exchanges (Choi, 1973; Adhikari and Tondkar, 1992). The culture in which the disclosing firm primarily operates also affects the 
level of disclosure (Gray, 1988; Perera, 1989; Gray and Vint, 1994; Zarzeski, 1996; Adhikari et al., 1998). Belgium, Germany and the Netherlands are dissimilar in terms of Hofstede's (1980) traditional cultural dimensions. Gray (1988) associates the Netherlands with a relatively high level of transparency, Germany with a high level of secrecy, and Belgium between the Netherlands and Germany; Belgium is more secretive than transparent. The accounting rules across these countries share some common characteristics, but are also unique in many ways. For instance, accounting in the Netherlands is quite comparable with AngloAmerican accounting. Financial reporting in Belgium and Germany are both strongly influenced by corporate law and taxation, but differ from each other in a number of respects, especially regarding the emphasis given to uniform accounting practices (Radebaugh and Gray, 1993). Leuz et al. (2002) classify Belgium, Germany and the Netherlands as insider economies with a strong legal enforcement. However, the three countries clearly show variation in their legal and institutional setting. First, comparatively speaking, the Netherlands has the highest outside investor rights, followed by Germany and Belgium (La Porta et al., 1998; Leuz et al., 2002). Second, the importance of the equity market as a source of firm capital is the highest in the Netherlands, followed by Belgium and Germany (La Porta et al., 1997; Leuz et al., 2002). Finally, there is large variation in ownership concentration among the three countries: ownership is most concentrated in Belgium, followed by Germany and the Netherlands (La Porta et al., 1998; Leuz et al., 2002).

The Robb et al. (2001) exploratory study developed an in-depth nonfinancial disclosure scoring system from the preferences of US and non-US financial analysts. Their study examined levels of business disclosures over and above those that are required by accounting standards. Unlike mandated financial disclosures, nonfinancial business disclosures are often voluntary and may even differ across similar cultures, as per the Adhikari et al. (1998) study. ${ }^{1}$ Robb et al. (2001) found significant differences in disclosure levels across three Anglo-American countries. We build on Robb et al. (2001) in an attempt to determine whether non-AngloAmerican firms provide similar nonfinancial disclosures. Given their observed differences in nonfinancial disclosures among Anglo-American markets, we would expect to see even more pronounced differences in reported nonfinancial information across countries that differ in terms of legal and institutional setting, financial accounting practices and culture. Although Hussein (1996) concludes that it is difficult to capture the richness and complexity of the 'culture-financial reporting' relationship, 
our study treats nonfinancial reporting as a possible harmonization solution for those companies active in the globalization of business and capital markets. The findings of our study could have important implications for the optimal and efficient allocation of investor resources across capital markets.

\subsection{Analysts' Forecasts}

In addition to determining whether companies across Continental Europe provide similar nonfinancial disclosures, we examine the value relevance of nonfinancial disclosures in a European context. Value relevance in this study refers to the usefulness of nonfinancial disclosures to financial analysts when preparing their earnings forecast estimates. Eccles et al. (2001) note that one of the best ways to get the market's attention (and financial analysts' attention) is to voluntarily provide much more information. In a mini-survey of high-tech companies, Eccles et al. (2001) found that $75 \%$ of financial analysts and $62 \%$ of investors agreed that better disclosure would increase analyst following in countries with low levels of analyst following.

Nichols (1989) and Schipper (1991) suggest that the behavior of analysts may provide indirect insights into the unobservable beliefs of investors. In particular, analysts' earnings forecast dispersion can be viewed as a measure of investors' uncertainty about a firm's future economic performance. While there is a substantial literature about the properties of analysts' earnings forecasts, there are no studies that consider how nonfinancial disclosures affect analysts' earnings forecasts. Jennings (1987) and Baginski and Hassell (1990) provide evidence that analysts revise their forecasts in response to the release of management forecasts and Waymire (1986) finds that the public release of management forecasts results in an increase in analysts' forecast accuracy. These findings suggest that additional disclosures by a firm can impact the accuracy and dispersion of analysts' forecasts. Lang and Lundholm (1996) examine the relationship between the disclosure practices of firms and analysts' behavior. They provide evidence that firms with more informative disclosure policies have a larger number of analysts following, more forecasts and less volatility in forecast revisions. Lang and Lundholm (1996) suggest that the potential benefits of disclosure include increased investor following, reduced estimation risk and reduced information asymmetry, all of which lead to a lower cost of capital for the firm. 
Although there has been some research on the effects of disclosures in an international setting (Saudagaran and Meek, 1997; Hope, 2001) and on the properties of analysts' earnings forecasts in an international setting (Basu et al., 1998; Chang et al., 2000, Hope, 2003), no prior multi-country study has examined the association between firm-level nonfinancial disclosures and forecast properties. As Hope (2001) suggests, given standard setters' emphasis on the importance of accounting policy disclosures, standard setters should be interested in whether the level of such disclosures is associated with real economic effects. We document these effects in our paper and suggest that our findings can be relevant for managers when developing corporate nonfinancial disclosure policies.

\section{Model and Hypotheses}

Our first objective is to identify factors that affect voluntary nonfinancial disclosure choices of firms in Belgium, Germany, and the Netherlands. We then examine the relationship of Jenkins Committee nonfinancial disclosure levels with the accuracy and dispersion of financial analysts' earnings forecasts for firms in these three countries. With respect to our first objective, we test the following hypothesis:

H1: The amount of voluntary nonfinancial disclosure differs across companies in Belgium, Germany and the Netherlands.

The empirical literature provides evidence that the extent of accounting disclosure varies among firms with respect to firm size, as measured by total assets, total sales, market value of the firm or total number of shareholders (Healy and Palepu, 1994; Ahmed and Courtis, 1999), industry, and listing on foreign exchanges (Choi, 1973; Adhikari and Tondkar, 1992). Listing on foreign exchanges is one indicator of an increased international scope of operations. International scope, or multinationality, has been measured in terms of the number of geographic segments and the level of foreign sales in profit-shifting studies (Klassen et al., 1993; Harris, 1993). To test H1, we employ the following model:

$$
\begin{aligned}
\operatorname{DISC}_{1 \ldots 6}= & a+b_{1}(\mathrm{SIZE})+b_{2}(\mathrm{IAS})+b_{3}(\mathrm{GEOSEG})+b_{4}(\mathrm{XLIST}) \\
& +b_{5}\left(\operatorname{IND}_{i}\right)+b_{6}(\mathrm{COUNTRY} \\
i & +e
\end{aligned}
$$

where:

DISC $_{1 \ldots 6}=$ an aggregate disclosure score for each of 6 categories including: environment around the company, strategy and management, 
company trends, environment of the company, production and customers (see the appendix for a listing of items in each disclosure category);

SIZE $=$ the natural log of total sales in constant (US) dollars;

IAS = a dummy variable indicating compliance with International Accounting Standards, where compliance with IAS is coded 1 and noncompliance is coded 0 ;

\#GEOSEG = the number of geographic segments a company reports;

XLIST $=$ the number of listings on foreign stock exchanges;

$\mathrm{IND}_{i}=$ dummy variables representing industry classification (7 industries; see Tables 2 and 3 for details);

COUNTRY $_{i}=$ dummy variables representing the country of domicile of each firm; and,

$e=$ error term.

A disclosure scoring system as in Robb et al. (2001) was developed to measure the extent of nonfinancial disclosures; see appendix. The disclosure scoring system is based on the List of Nonfinancial Information Desired by Users from the AICPA Jenkins Committee database. The information items were grouped into six categories: (1) the environment around the company, (2) strategy and management, (3) company trends, (4) the environment of the company, (5) production and (6) customers. The first three categories represent forward-looking nonfinancial disclosures. The last three categories represent historical nonfinancial disclosures.

The control variables are chosen in part based on prior research. Consistent with the established literature, we predict positive signs on SIZE, IAS, \#GEOSEG, and XLIST since nonfinancial disclosures have been shown to be positively associated with larger companies, companies which comply with international accounting standards, companies with larger numbers of geographic segments and companies that are listed on multiple exchanges. We expect that the level of nonfinancial disclosure, both forward looking and historical, is higher in the Netherlands compared to Germany and Belgium. This expectation stems from the fact that the Netherlands is characterized by a higher level of transparency, a more developed equity market and a lower level of ownership concentration compared to Germany and Belgium.

Our second objective is to examine the relationship of nonfinancial disclosures with analysts' forecast accuracy and dispersion. Specifically, we test the following hypotheses: 
$\mathrm{H} 2$ : The dispersion of analysts' earnings forecasts is negatively related to the level of voluntary nonfinancial information.

H3: The accuracy of analysts' earnings forecasts is positively related to the level of voluntary nonfinancial information.

We measure dispersion by the standard deviation of analysts' forecasts divided by the absolute value of the mean analyst forecast for an individual company. Accuracy is measured by the absolute value of the difference between the mean analysts' forecasts and the actual earnings of the firm, scaled by actual earnings.

Barron et al. (1999) show that, in a theoretical model, under certain conditions, firm-provided disclosures have a greater impact on forecast dispersion than on forecast accuracy. In particular, when information asymmetry among analysts is above a certain threshold, increased public disclosure has a greater impact on forecast dispersion than on forecast error, since public disclosure draws all forecasts closer to actual earnings realizations while also causing a reduction in asymmetry. Consistent with this prediction, Lang and Lundholm (1996) find a negative (positive) association between total annual report disclosure ratings by the Association for Investment Management and Research (AIMR) and forecast dispersion (accuracy) in the US. The dispersion of analysts' forecasts reflects uncertainty about firms' future economic performance (Barron and Stuerke, 1998). Although theory suggests that increased disclosure can either increase or decrease forecast dispersion (Harris and Raviv, 1993), most arguments support an association with reduced forecast dispersion.

No prior study has investigated the association between firm-level forward looking and historical voluntary nonfinancial disclosures and earnings forecast properties. It is questionable whether financial analysts consider both forward-looking and historical nonfinancial disclosures as containing equally useful information. If so, we would expect that forward looking and historical nonfinancial disclosures lead to more accuracy and less dispersion in the earnings forecasts among financial analysts.

To test $\mathrm{H} 2$ and $\mathrm{H} 3$, we employ the following models:

\section{Model 1: Total disclosure}

$$
\begin{aligned}
\mathrm{DISP}= & a+b_{1}(\mathrm{SIZE})+b_{2}(\mathrm{LTD} / \mathrm{CE})+b_{3}(\mathrm{ROE})+b_{4}\left(\mathrm{COUNTRY}_{i}\right) \\
& +b_{5}(\mathrm{NOEST})+b_{6}(\mathrm{DEAR})+b_{7}(\mathrm{TD})+e
\end{aligned}
$$




$$
\begin{aligned}
\mathrm{ACC}= & a+b_{1}(\mathrm{SIZE})+b_{2}(\mathrm{LTD} / \mathrm{CE})+b_{3}(\mathrm{ROE})+b_{4}\left(\mathrm{COUNTRY}_{i}\right) \\
& +b_{5}(\mathrm{NOEST})+b_{6}(\Delta \mathrm{EAR})+b_{7}(\mathrm{TD})+e
\end{aligned}
$$

Model 2: Subdivision disclosure

$$
\begin{aligned}
\mathrm{DISP}= & a+b_{1}(\mathrm{SIZE})+b_{2}(\mathrm{LTD} / \mathrm{CE})+b_{3}(\mathrm{ROE})+b_{4}\left(\mathrm{COUNTRY}_{i}\right) \\
& +b_{5}(\mathrm{NOEST})+b_{6}(\Delta \mathrm{EAR})+b_{7}(\mathrm{TFLD})+b_{8}(\mathrm{THD})+e \\
\mathrm{ACC}= & a+b_{1}(\mathrm{SIZE})+b_{2}(\mathrm{LTD} / \mathrm{CE})+b_{3}(\mathrm{ROE})+b_{4}\left(\mathrm{COUNTRY}_{i}\right) \\
& +b_{5}(\mathrm{NOEST})+b_{6}(\Delta \mathrm{EAR})+b_{7}(\mathrm{TFLD})+b_{8}(\mathrm{THD})+e
\end{aligned}
$$

where:

DISP $=$ the dispersion in analysts' earnings forecasts;

$\mathrm{ACC}=$ the accuracy of analysts' earnings forecasts;

SIZE $=$ the natural logarithm of total sales;

$\mathrm{LTD} / \mathrm{CE}=$ long-term debt divided by common equity;

$\mathrm{ROE}=$ return on equity;

COUNTRY $_{i}=$ dummy variables representing the country of domicile of each firm;

NOEST $=$ the number of financial analysts following the company;

$\triangle \mathrm{EAR}=$ the absolute value of the change in earnings from the prior year, scaled by total sales;

$\mathrm{TD}=$ the total nonfinancial disclosures (i.e., TFLD + THD);

TFLD $=$ the total forward looking nonfinancial disclosures (i.e., environment around the company (DISC 1)+strategy and management (DISC 2) + company trends (DISC 3));

$\mathrm{THD}=$ the total historical nonfinancial disclosures (i.e., environment of the company (DISC 4)+ production (DISC 5)+ customers (DISC 6));

$e=$ the error term.

Each of the above variables is firm specific. Equations (2) and (3) of model 1 focus on the impact of the total level of nonfinancial disclosures on the dispersion and accuracy of analysts' earnings forecasts. In equations (4) and (5) of model 2 a distinction is made between forward-looking nonfinancial disclosures and historical nonfinancial disclosures.

We select control variables consistent with those employed in prior studies (see for example Hope, 2001). First, we control for factors related to the management environment. In this respect, we include three control variables: firm size, measured by the natural logarithm of total sales (SIZE); leverage, measured by long-term debt divided by common equity (LTD/CE); and profitability, measured by return on equity (ROE). 
Second, we control for factors related to cross-country variations in management incentives and the ability to manage earnings by using dummy variables for the country of domicile of each firm (COUNTRY $)_{i}$. Third, we control for factors related to the analyst environment. In particular, we control for competitive pressure among analysts, as measured by the number of analysts (NOEST) following each company. We also attempt to control for analysts' task complexity as measured by the change in earnings from the prior year, scaled by sales (i.e., a measure of earnings surprise).

\section{Data}

This study includes a 120-company sample of Belgian, German and Dutch companies from the following manufacturing industries: automobiles, chemicals, construction, electronic equipment, machinery \& equipment, metal, and pharmaceuticals. These industries were selected since they disclose a significant amount of information in their annual reports and typically engage in a considerable volume of international business transactions.

Given the time-consuming process of coding the annual reports, our objective was to compose a representative sample of 120 firms, equally divided between Belgium, Germany and the Netherlands. For the selected manufacturing industries, we determined the number of companies that were followed by IBES at the time.It was not possible to identify a sample of 40 Belgium companies for which forecast data and annual report data were available. (Data were available for only 32 Belgium companies.) Hence, it was decided to increase both the sample of Dutch and German companies by 4 to achieve a total sample size of 120 . If a sufficient number of companies were followed by IBES in a particular industry in Germany or the Netherlands, we randomly selected companies from that industry. For certain industries, however, none or only a small number of companies were followed by IBES (for example, the pharmaceuticals and metal industries in the Netherlands). To compensate for this, we increased the number of companies in other industries for which forecast data was available on a random basis (for example, the construction and machinery $\&$ equipment industries in the Netherlands). This resulted in a total sample size of 120 companies: 32 in Belgium, 44 in Germany, and 44 in the Netherlands.

We collected corporate annual reports for the 120 firms described above. The home-language annual report was read by the same author, 
cover to cover, to obtain a disclosure score and the independent variable measures. The coding was validated for a random subsample in each country by a second individual. The disclosure-scoring sheet in the appendix shows the categories of nonfinancial and financial disclosures encoded for each company.

To classify the information from each annual report, we used a detailed nonfinancial disclosure scoring system based specifically on the List of Nonfinancial Information Desired by Users from the AICPA Jenkins Committee database (see Appendix). The detailed information items were then grouped into the following six categories: the environment around the company, strategy and management, company trends, the environment of the company, production and customers. Each category contains: (1) information that likely exists about every company and (2) information that financial analysts and investors have indicated is important for company valuation. A rate of 0 (no disclosure) or 1 (disclosure) was given to each disclosure item.

In addition to annual reports and IBES forecast data, we gathered Worldscope data for 1999. All of our sample companies are followed by IBES. The International Brokers' Estimate System provided analysts' annual earnings forecasts, actual annual earnings, standard deviation of analysts' forecasts, and the number of financial analysts following each company. We used the forecasts from the end of the month preceding the earnings announcement, i.e., the one-month ahead forecast. ${ }^{2}$ There are 32 Belgian, 44 German and 44 Dutch companies in our sample. A single year of data (1999) was examined in order to eliminate potential confounding effects of changes in reporting standards or practices over time. All financial data were converted to US dollars using the appropriate spot rate as of the company's balance sheet date.

\section{Results}

\subsection{Descriptive Statistics}

Mean disclosure scores by country are reported in Table 1 . The scores are the sums of the ratings ( 0 or 1$)$ for each of the specific disclosure items in each of the major categories (see the appendix for the disclosure checklist items). For example, the category 'environment around the company' contains twelve specific items. Thus, the total score possible for this category could range from zero to twelve. ${ }^{3}$ 


\begin{tabular}{|c|c|c|c|}
\hline Dependent Variables & Netherlands $n=44$ & Belgium $n=32$ & Germany $n=44$ \\
\hline Forward-Looking Nonfinancial Disclosure & Mean & Mean & Mean \\
\hline Environment Around Company (EACO) (maximum score of 12) & 3.90 & 3.00 & 3.09 \\
\hline Strategy (STGY) (maximum score of 14) & 6.75 & 6.68 & 6.13 \\
\hline Trends (TRDS) (maximum score of 5) & 1.61 & 1.21 & 1.18 \\
\hline Total Forward Looking Disclosures (maximum score of 31) & 12.27 & 10.90 & 10.56 \\
\hline \multicolumn{4}{|l|}{ Historical Nonfinancial Disclosure } \\
\hline Environment of Company (EFCO) (maximum score of 7) & 2.97 & 2.68 & 2.52 \\
\hline Production (PROD) (maximum score of 18) & 5.50 & 5.53 & 5.72 \\
\hline Customers (CUST) (maximum score of 9) & 1.72 & 2.00 & 1.68 \\
\hline Total Historical Disclosures (maximum score of 34) & 10.20 & 10.21 & 9.93 \\
\hline Total Disclosure Score (maximum score of 65) & 22.47 & 21.12 & 20.50 \\
\hline \multicolumn{4}{|l|}{ Independent Variables } \\
\hline Mean number of Geographic Segments (\#GEOSEG) & 3.31 & 2.56 & 2.77 \\
\hline Mean sales in millions of US\$ (SIZE) & 1,305 & 1,384 & 6,243 \\
\hline Number of firms with listings on foreign exchanges (XLIST)* & 5 & 5 & 24 \\
\hline
\end{tabular}

* The average number of cross-listings per firm is 0.5 for the Netherlands, 0.43 for Belgium, and 1.06 for Germany. The correlation between cross-listing and firm size and between number of geographic segments and firm size is 0.656 and 0.213 , respectively. The correlations between cross-listing and country, between cross-listing and industry and between cross-listing and number of geographic segments are $-.15,0.21$ and 0.32 , respectively.

Note: Refer to Appendix A for the detailed disclosures comprising each of the six composite categories. 
Table 2. Descriptive Statistics by Industry (Mean Values)

\begin{tabular}{lcc}
\hline Industry & $\begin{array}{c}\text { Number of } \\
\text { Geographic } \\
\text { Segments } \\
\text { (\#GEOSEG) }\end{array}$ & $\begin{array}{c}\text { Sales in } \\
\text { US\$ } \\
\text { (SIZE) }\end{array}$ \\
\hline Automotive & 3.07 & $6,856,407$ \\
Chemicals & 1.73 & $4,229,621$ \\
Construction & 2.38 & $1,313,386$ \\
Electrical Equipment & 2.09 & $3,602,272$ \\
Machinery \& Equipment & 2.57 & 609,916 \\
Metal & 3 & $6,648,550$ \\
Pharmaceuticals & 3 & $2,466,522$ \\
\hline
\end{tabular}

Table 3. Descriptive Statistics: Number of Firms Country $\times$ Industry

\begin{tabular}{lcccr}
\hline Industry & Netherlands & Belgium & Germany & Total \\
\hline Automotive & 7 & 1 & 6 & 14 \\
Chemicals & 5 & 8 & 6 & 19 \\
Construction & 10 & 5 & 6 & 21 \\
Electrical Equipment & 8 & 7 & 7 & 22 \\
Machinery \& Equipment & 13 & 7 & 6 & 26 \\
Metal & 0 & 3 & 5 & 8 \\
Pharmaceuticals & 1 & 32 & 4 & 10 \\
Total & 44 & &
\end{tabular}

The Dutch companies have the highest level of total forward-looking nonfinancial disclosure and the highest level in all three individual forward-looking nonfinancial disclosure categories. Belgium and the Netherlands have a similar level of total historical disclosures, followed by Germany.

Table 2 reports mean sales and the number of geographic segments by industry. The automotive industry is the largest in terms of sales dollars and it is the most geographically dispersed. The chemical industry is the least geographically dispersed in terms of number of geographic segments. Electrical equipment is the smallest in terms of sales dollars. Table 3 shows the industry by country breakdown of the firms included in the sample.

\subsection{Test of Means Statistics}

The tests of means are reported in Table 4 and provide support for Hypothesis 1 . Germany and the Netherlands provide statistically different levels of total forward-looking nonfinancial disclosures $(\mathrm{p}<0.05)$, with 
Table 4. Test of Means. Nonfinancial Disclosure Scores by Country

\begin{tabular}{lllc}
\hline Dependent Variables & Netherlands & Belgium & Germany \\
\hline Total Forward Looking Disclosures & 12.27 (a),(b) & 10.90 (b) & 10.56 (a) \\
Total Historical Disclosures & 10.20 & 10.21 & 9.93
\end{tabular}

(a) The Netherlands and Germany are statistically different, Bonferroni-test: Mean difference $=1.70$, Sig. 0.018 (1-sided).

(b) The Netherlands and Belgium are statistically different, Bonferroni-test: Mean difference $=1.36$, Sig. 0.09 (1-sided).

Table 5. Tests of National Influences on Analysts' Characteristics

Panel A: Mean Analysts' Characteristics Data

\begin{tabular}{llll}
\hline Analysts' Characteristics & Netherlands & Belgium & Germany \\
\hline Number of analysts (a) & 17.09 & 8.60 & 13.73 \\
Dispersion of Analysts' Earnings forecasts (b) & 0.24 & 0.16 & 0.28 \\
Accuracy of Analysts' Earnings forecasts* (c) & 0.30 & 0.66 & 0.52 \\
\hline
\end{tabular}

Panel B: ANOVA Results

\begin{tabular}{lcc}
\hline \multirow{2}{*}{ Analysts' Characteristics } & \multicolumn{2}{c}{ Source of variation: Country } \\
\cline { 2 - 3 } & F-value & Significance \\
\hline Number of analysts & 6.16 & 0.03 \\
Dispersion of Analysts' Earnings forecasts & 0.80 & 0.44 \\
Accuracy of Analysts' Earnings forecasts & 2.03 & 0.13 \\
\hline
\end{tabular}

(a) The Netherlands is significantly different from Germany and Belgium at 0.05 level.

(b) Belgium is significantly different from Germany and the Netherlands at respectively 0.05 and 0.1 level.

(c) The Netherlands is significantly different from Germany and Belgium at respectively 0.1 and 0.05 level.

*Note: A low reported value indicates a high accuracy.

Belgium providing a level of disclosure between that of the other two countries. However, total historical nonfinancial disclosures are not statistically different among these countries.

Table 5 reports the test results of the relationships between analyst characteristics and country. Panel A describes mean analysts' characteristics by country. The largest number of analysts is found in the Netherlands, followed by Germany and Belgium. The dispersion of 
analysts' forecasts of earnings is the highest in Germany, followed by the Netherlands and Belgium. The accuracy ${ }^{4}$ of analysts' forecasts is the highest in the Netherlands, followed by Germany and Belgium. This finding, in light of the country-by-country differences reported in Table 4 suggests that higher total disclosure by firms improves analysts' accuracy and reduces the dispersion among their forecasts, and provides support for $\mathrm{H} 2$ and $\mathrm{H} 3$. The Netherlands has the highest disclosure level of forwardlooking nonfinancial information and the highest analyst forecast accuracy.

Panel A of Table 5 presents by country, the average number of analysts following the companies in our sample and the mean dispersion and accuracy of analysts' earnings forecasts. The average number of analysts following our sample of Dutch, Belgium and German companies is 17.09, 8.60 and 13.73 respectively. The dispersion in analysts' earnings forecasts, measured as the standard deviation of analysts' forecasts divided by the absolute value of the mean analyst forecast for an individual company, is on average 0.24 in the Netherlands, 0.16 in Belgium, and 0.28 in Germany. The accuracy of the analysts' earnings forecasts, measured by the absolute value of the difference between the mean analysts' forecasts and the actual earnings of the firm, scaled by actual earnings is on average 0.30 in the Netherlands, 0.66 in Belgium and 0.52 in Germany. Panel B of Table 5 indicates that the number of analysts following a sample firm varies significantly by country. Therefore, it is possible that the combination of low dispersion and low accuracy in Belgium (in Panel A) is due to the low number of analysts following the sample companies in that country. In the next section, we conduct regression tests to condition on factors that may help explain the unconditional results reported in Tables 4 and 5.

\subsection{Regression Statistics}

We estimate equation (1) using seemingly unrelated regression (SUR) since the dependent variables are correlated. ${ }^{5}$ The dependent variables are the sums ranging from 0 to 65 of the $0-1$ ratings for the specific disclosure items in each of the six major disclosure categories. We use the Netherlands as the base country so we use dummy variables for Germany and Belgium only. Results of the regressions for forward looking and historical disclosures, and for each of the six disclosure categories are reported in Table $6 \mathrm{a}$ and Table $6 \mathrm{~b}$ respectively.

The results in Table 6a show that the level of total forward looking nonfinancial disclosures is significantly lower in both Germany and 
Table 6a. Total Forward Looking Nonfinancial Disclosure Model $^{1}$

\begin{tabular}{|c|c|c|}
\hline \multicolumn{3}{|c|}{ Coefficient estimate (z-statistic) } \\
\hline Indep.variables $^{2}$ & Total forward-looking disclosure & Total historical disclosure \\
\hline \multirow[t]{2}{*}{ CONSTANT } & 0.866 & $5.439^{* * * *}$ \\
\hline & $(0.353)$ & $(3.102)$ \\
\hline \multirow[t]{2}{*}{ SIZE } & $0.907 * * *$ & $0.442^{* * * *}$ \\
\hline & (4.779) & (3.261) \\
\hline \multirow[t]{2}{*}{ IAS } & -0.840 & 0.932 \\
\hline & $(-0.666)$ & $(1.035)$ \\
\hline \multirow[t]{2}{*}{ GEOSEG } & -0.041 & -0.015 \\
\hline & $(-0.324)$ & $(-0.174)$ \\
\hline \multirow[t]{2}{*}{ XLIST } & 0.049 & 0.128 \\
\hline & $(0.104)$ & $(0.373)$ \\
\hline \multirow[t]{2}{*}{ CHEM } & 0.477 & -1.014 \\
\hline & $(0.505)$ & $(-1.502)$ \\
\hline \multirow[t]{2}{*}{$\mathrm{CON}$} & -0.691 & $-1.470^{* * *}$ \\
\hline & $(-0.819)$ & $(-2.439)$ \\
\hline \multirow[t]{2}{*}{$\mathrm{EE}$} & -0.398 & $-1.489 * *$ \\
\hline & $(-0.449)$ & $(-2.348)$ \\
\hline \multirow[t]{2}{*}{ ME } & -0.164 & -0.566 \\
\hline & $(-0.197)$ & $(-0.951)$ \\
\hline \multirow[t]{2}{*}{ MET } & -1.007 & -0.798 \\
\hline & $(-0.867)$ & $(-0.963)$ \\
\hline \multirow[t]{2}{*}{ PHAR } & $2.358 * *$ & -1.078 \\
\hline & $(2.109)$ & $(-1.350)$ \\
\hline \multirow[t]{2}{*}{ GER } & $-2.823^{* * * *}$ & $-0.835^{*}$ \\
\hline & $(-4.462)$ & $(-1.849)$ \\
\hline \multirow[t]{2}{*}{ BEL } & $-1.442^{* *}$ & 0.129 \\
\hline & $(-2.272)$ & $(0.286)$ \\
\hline Chi-squared & 63.508 & 37.508 \\
\hline $\mathrm{p}$-value of model & 0.000 & 0.000 \\
\hline R-squared & 0.346 & 0.238 \\
\hline Adjusted R-squared & 0.281 & 0.152 \\
\hline $\mathrm{N}$ & 120 & 120 \\
\hline
\end{tabular}

${ }^{1}$ The table reports seemingly unrelated regression coefficients with z-statistics: ${ }^{*} \mathrm{p}<.10, * * \mathrm{p}<.05, * * * \mathrm{p}<.01$.

${ }^{2}$ SIZE: Natural log of total sales in US\$

IAS = Reporting in compliance with International Accounting Standards (dummy variable).

GEOSEG $=$ number of geographic segments, XLIST = number of listings on a foreign stock exchange.

Industry Classifications: AUTO = automotive (industry of reference), CHEM $=$ chemicals, $\mathrm{CON}=$ construction, $\mathrm{EE}=$ electrical equipment, $\mathrm{ME}=$ machinery and equipment, $\mathrm{MET}=$ metal, PHAR = pharmaceuticals

Countries: BEL $=$ Belgium, GER $=$ Germany, NETH $=$ Netherlands (country of reference).

Belgium, compared to the Netherlands (support for hypothesis 1). When considering the three forward looking nonfinancial disclosure categories separately, Germany scores significantly lower in each category. Belgium differs significantly from the Netherlands in two categories (environment 
Table 6b. Subdivision of Forward Looking and Historical Nonfinancial Disclosure Models ${ }^{1}$

\begin{tabular}{|c|c|c|c|c|c|c|}
\hline & \multicolumn{6}{|c|}{ Dependent variables $^{2}$} \\
\hline & \multicolumn{6}{|c|}{ Coefficient estimate (z-statistic) } \\
\hline & \multicolumn{3}{|c|}{ Forward Looking Disclosures } & \multicolumn{3}{|c|}{ Historical Disclosures } \\
\hline & EACO & STGY & TRDS & $\mathrm{EFCO}$ & PROD & CUST \\
\hline \multicolumn{7}{|l|}{ Independent variables ${ }^{3}$} \\
\hline CONSTANT & $\begin{array}{c}-0.759 \\
(-0.651)\end{array}$ & $\begin{array}{c}1.246 \\
(0.844)\end{array}$ & $\begin{array}{c}0.647 \\
(1.342)\end{array}$ & $\begin{array}{c}0.642 \\
(0.979)\end{array}$ & $\begin{array}{l}3.856^{\text {***** }} \\
(3.214)\end{array}$ & $\begin{array}{c}0.940 \\
(1.147)\end{array}$ \\
\hline SIZE & $\begin{array}{l}0.441^{\text {***** }} \\
(4.885)\end{array}$ & $\begin{array}{l}0.356^{\text {***** }} \\
(3.123)\end{array}$ & $\begin{array}{l}0.084 * * \\
(2.257)\end{array}$ & $\begin{array}{l}0.188 * * \\
(3.718)\end{array}$ & $\begin{array}{l}0.192 * * \\
(2.077)\end{array}$ & $\begin{array}{c}0.060 \\
(0.957)\end{array}$ \\
\hline IAS & $\begin{array}{c}0.373 \\
(0.623)\end{array}$ & $\begin{array}{c}-1.035 \\
(-1.366)\end{array}$ & $\begin{array}{c}-0.213 \\
(-0.863)\end{array}$ & $\begin{array}{l}0.756^{* * *} \\
(2.244)\end{array}$ & $\begin{array}{c}0.162 \\
(0.264)\end{array}$ & $\begin{array}{c}0.013 \\
(0.031)\end{array}$ \\
\hline GEOSEG & $\begin{array}{l}-0.135^{* * *} \\
(-2.236)\end{array}$ & $\begin{array}{l}0.160 * * \\
(2.094)\end{array}$ & $\begin{array}{l}-0.035 \\
(-1.424)\end{array}$ & $\begin{array}{l}-0.059^{* * * *} \\
(-1.754)\end{array}$ & $\begin{array}{c}-0.041 \\
(-0.673)\end{array}$ & $\begin{array}{l}0.085^{* * *} \\
(2.018)\end{array}$ \\
\hline XLIST & $\begin{array}{c}-0.127 \\
(-0.557)\end{array}$ & $\begin{array}{c}0.313 \\
(1.083)\end{array}$ & $\begin{array}{c}-0.107 \\
(-1.135)\end{array}$ & $\begin{array}{c}0.043 \\
(0.340)\end{array}$ & $\begin{array}{c}-0.066 \\
(-0.284)\end{array}$ & $\begin{array}{c}0.151 \\
(0.941)\end{array}$ \\
\hline CHEM & $\begin{array}{c}-0.287 \\
(-0.639)\end{array}$ & $\begin{array}{c}0.572 \\
(1.006)\end{array}$ & $\begin{array}{c}0.013 \\
(0.074)\end{array}$ & $\begin{array}{l}0.463^{* * * * *} \\
(1.832)\end{array}$ & $\begin{array}{c}-0.689 \\
(-1.491)\end{array}$ & $\begin{array}{l}-0.788^{* * *} \\
(-2.498)\end{array}$ \\
\hline $\mathrm{CON}$ & $\begin{array}{l}-0.933 * * * \\
(-2.324)\end{array}$ & $\begin{array}{c}0.111 \\
(0.219)\end{array}$ & $\begin{array}{c}0.135 \\
(0.817)\end{array}$ & $\begin{array}{c}0.137 \\
(0.609)\end{array}$ & $\begin{array}{l}-1.012^{* *} \\
(-2.465)\end{array}$ & $\begin{array}{l}-0.596^{* *} \\
(-2.115)\end{array}$ \\
\hline $\mathrm{EE}$ & $\begin{array}{l}-0.823 * \\
(-1.949)\end{array}$ & $\begin{array}{c}0.471 \\
(0.883)\end{array}$ & $\begin{array}{c}-0.071 \\
(-0.411)\end{array}$ & $\begin{array}{c}-0.049 \\
(-0.210)\end{array}$ & $\begin{array}{l}-1.141^{\text {***** }} \\
(-2.631)\end{array}$ & $\begin{array}{c}-0.297 \\
(-1.005)\end{array}$ \\
\hline ME & $\begin{array}{l}-0.499 \\
(-1.260)\end{array}$ & $\begin{array}{c}0.320 \\
(0.640)\end{array}$ & $\begin{array}{c}-0.021 \\
(-0.134)\end{array}$ & $\begin{array}{c}0.067 \\
(0.305)\end{array}$ & $\begin{array}{l}-0.532 \\
(-1.307)\end{array}$ & $\begin{array}{c}-0.102 \\
(-0.366)\end{array}$ \\
\hline MET & $\begin{array}{l}-1.076^{* * * * *} \\
(-1.949)\end{array}$ & $\begin{array}{c}0.345 \\
(0.494)\end{array}$ & $\begin{array}{c}-0.263 \\
(-1.156)\end{array}$ & $\begin{array}{c}0.480 \\
(1.546)\end{array}$ & $\begin{array}{c}-0.574 \\
(-1.013)\end{array}$ & $\begin{array}{l}-0.703^{*} \\
(-1.816)\end{array}$ \\
\hline PHAR & $\begin{array}{l}-0.141 \\
(-0.266)\end{array}$ & $\begin{array}{l}1.690^{* * *} \\
(2.513)\end{array}$ & $\begin{array}{c}0.336 \\
(1.530)\end{array}$ & $\begin{array}{c}-0.314 \\
(-1.052)\end{array}$ & $\begin{array}{c}-0.701 \\
(-1.284)\end{array}$ & $\begin{array}{c}-0.061 \\
(-0.165)\end{array}$ \\
\hline GER & $\begin{array}{l}-1.317 * * * * \\
(-4.379)\end{array}$ & $\begin{array}{l}-1.091^{\text {****** }} \\
(-2.869)\end{array}$ & $\begin{array}{l}-0.468^{* * * * *} \\
(-3.768)\end{array}$ & $\begin{array}{l}-0.772^{* * * * * k} \\
(-4.564)\end{array}$ & $\begin{array}{c}0.027 \\
(0.088)\end{array}$ & $\begin{array}{c}-0.090 \\
(-0.426)\end{array}$ \\
\hline BEL & $\begin{array}{l}-0.950 \text { ***** } \\
(-3.147)\end{array}$ & $\begin{array}{c}-0.049 \\
(-0.129)\end{array}$ & $\begin{array}{l}-0.393^{* * * *} \\
(-3.156)\end{array}$ & $\begin{array}{l}-0.424 * * \\
(-2.499)\end{array}$ & $\begin{array}{c}0.080 \\
(0.258)\end{array}$ & $\begin{array}{l}0.474 * * \\
(2.237)\end{array}$ \\
\hline Chi-squared & 57.682 & 54.665 & 33.883 & 60.519 & 18.610 & 24.198 \\
\hline $\mathrm{p}$-value & 0.000 & 0.000 & 0.000 & 0.000 & 0.098 & 0.019 \\
\hline $\mathrm{R}$-squared & 0.324 & 0.313 & 0.220 & 0.335 & 0.134 & 0.167 \\
\hline Adjusted R-squared & 0.265 & 0.230 & 0.130 & 0.260 & 0.038 & 0.068 \\
\hline $\mathrm{N}$ & 120 & 120 & 120 & 120 & 120 & 120 \\
\hline
\end{tabular}

${ }^{1}$ The table reports seemingly unrelated regression coefficients with z-statistics:

${ }^{*} \mathrm{p}<.10,{ }^{* *} \mathrm{p}<.05, * * * \mathrm{p}<.01$.

${ }^{2}$ Forward Looking Disclosures: $E A C O=$ environment around the company, $S T G Y=$ strategy and management, $T R D S=$ trends,

Historical Disclosures: $E F C O=$ environment of the company, $P R O D=$ production, $C U S T=$ customers and markets.

${ }^{3}$ SIZE: Natural log of total sales in US\$

IAS $=$ Reporting in compliance with International Accounting Standards (dummy variable); GEOSEG $=$ number of geographic segments; XLIST = number of listings on a foreign stock exchange.

Industry Classifications: AUTO $=$ automotive (industry of reference), CHEM $=$ chemicals, $\mathrm{CON}=$ construction, $\mathrm{EE}=$ electrical equipment, $\mathrm{ME}=$ machinery and equipment, $\mathrm{MET}=$ metal, PHAR = pharmaceuticals.

Countries: $\mathrm{BEL}=$ Belgium, GER $=$ Germany, $\mathrm{NETH}=$ Netherlands (country of reference). 
around the company and trends). With respect to historical nonfinancial disclosures, it appears that Germany provides a significantly lower level of total disclosure than the Netherlands. In particular, German companies provide a significantly lower level of disclosure related to the environment of the company. Belgium differs significantly from the Netherlands in the environment of the company and customers categories.

Table $6 \mathrm{a}$ and $6 \mathrm{~b}$ shows that firm size is positively and significantly related to the level of total forward looking nonfinancial disclosures and the level of total historical nonfinancial disclosures. With respect to the individual disclosure categories, firm size is positively and significantly related with the environment around the company, strategy and management, trends, environment of the company and production. Contrary to our expectations, companies reporting in compliance with IAS do not disclose more nonfinancial information in any significant way, except for the category 'environment of the company'.

Consistent with prior literature and as expected, industry classification is significant. The pharmaceutical industry provides significantly more forward looking nonfinancial information, while construction and electrical equipment provide significantly less historical nonfinancial disclosures. The differences in industry significance across disclosure categories may result from the unavoidable use of dummy variables to encode these measures.

Contrary to our expectations, the level of nonfinancial disclosure does not appear to be directly related to the degree of geographic dispersion (GEOSEGM) or to the number of listings on a foreign stock exchange (XLISTINGS). However, the lack of evidence may be due to multicollinearity. Indeed, the Pearson correlation matrix (not reported) indicates that total sales are strongly correlated with the number of listings on a foreign stock exchange. Therefore, we re-run our seemingly unrelated regressions without the size variable. The results are presented in Table 7.

In Table 7, both GEOSEGM and XLISTINGS have a positive, significant sign for the level of total forward-looking nonfinancial disclosures. The level of total historical nonfinancial disclosures is also significantly higher when companies list on more foreign stock exchanges. Consequently, these results suggest that companies with a global focus provide higher levels of nonfinancial disclosures in their annual reports.

We now turn to the results for earnings forecasts based on models 1 and 2. The regression results with respect to the dispersion and accuracy of analysts' earnings forecasts are presented in Table 8. 
Table 7. Nonfinancial Disclosure Models (without SIZE Variable) ${ }^{1}$

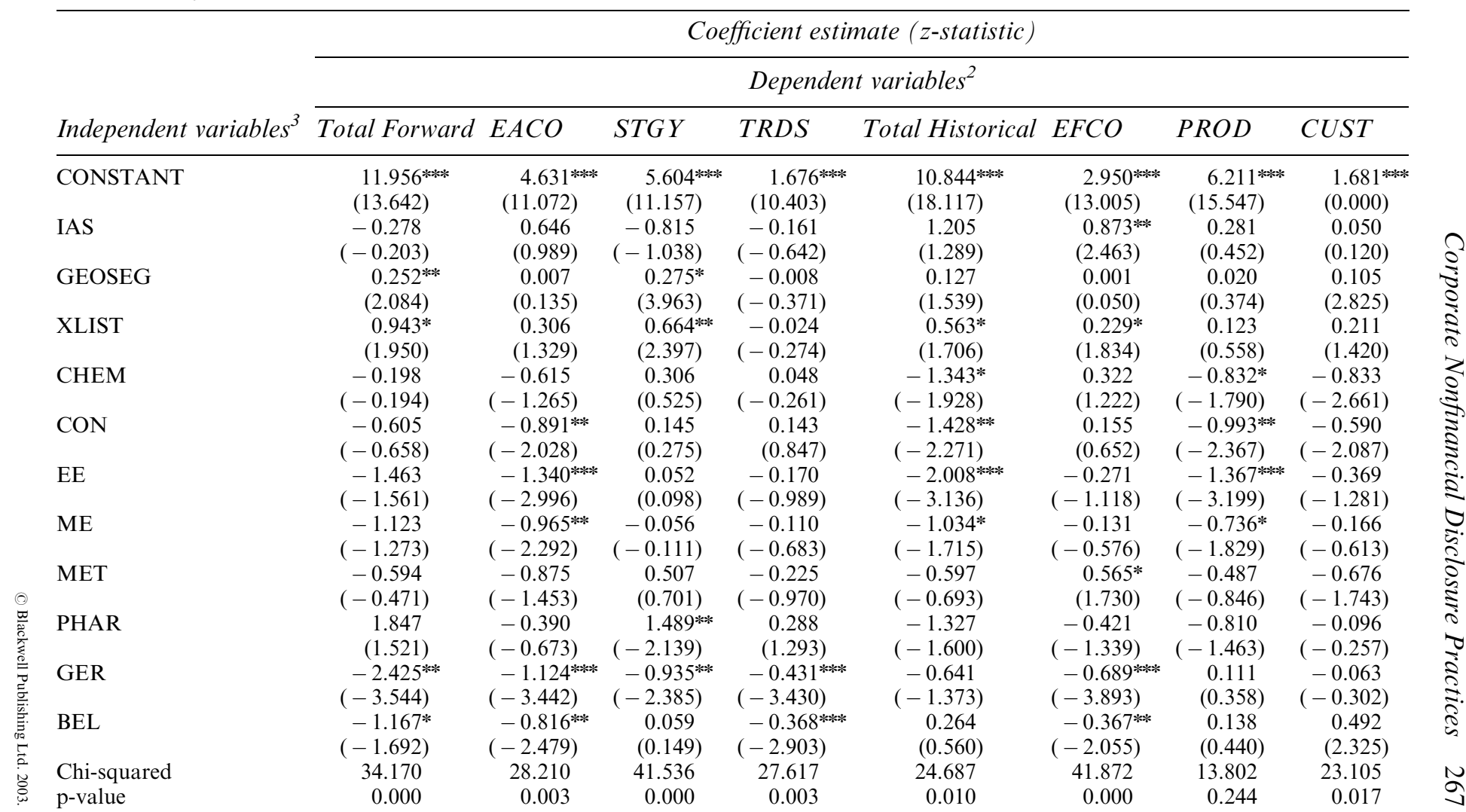




\begin{tabular}{|c|c|c|c|c|c|c|c|c|}
\hline \multirow[b]{3}{*}{ Independent variables ${ }^{3}$} & \multicolumn{8}{|c|}{ Coefficient estimate (z-statistic) } \\
\hline & \multicolumn{8}{|c|}{ Dependent variables $^{2}$} \\
\hline & Total Forward & $E A C O$ & $S T G Y$ & $T R D S$ & Total Historical & $E F C O$ & $P R O D$ & CUST \\
\hline R-squared & 0.221 & 0.190 & 0.257 & 0.187 & 0.170 & 0.258 & 0.103 & 0.161 \\
\hline Adjusted R-squared & 0.128 & 0.100 & 0.155 & 0.104 & 0.092 & 0.182 & 0.025 & 0.065 \\
\hline $\mathrm{N}$ & 120 & 120 & 120 & 120 & 120 & 120 & 120 & 120 \\
\hline
\end{tabular}

${ }^{1}$ The table reports seemingly unrelated regression coefficients with z-statistics:

$* \mathrm{p}<.10, * * \mathrm{p}<.05, * * * \mathrm{p}<.01$.

${ }^{2} T F L D=$ total forward looking disclosure, $T H D=$ total historical disclosure, $E A C O=$ environment around the company, $S T G Y=$ strategy and management, $T R D S=$ trends, $E F C O=$ environment of the company, $P R O D=$ production, $C U S T=$ customers and markets.

${ }^{3} \mathrm{IAS}=$ Reporting in compliance with International Accounting Standards (Dummy variable)

GEOSEGM $=$ number of geographic segments, XLIST $=$ number of listings on a foreign stock exchange.

Industry Classifications: AUTO = automotive (industry of reference), $\mathrm{CHEM}=$ chemicals, $\mathrm{CON}=$ construction; $\mathrm{EE}=$ electrical equipment, $\mathrm{ME}=$

machinery and equipment, MET $=$ metal, PHAR $=$ pharmaceuticals.

Countries: BEL = Belgium, GER $=$ Germany, NETH $=$ Netherlands (country of reference). 
Table 8. Dispersion and Accuracy of Analysts' Earnings Forecasts Models ${ }^{1}$

\begin{tabular}{|c|c|c|c|c|}
\hline \multirow[b]{5}{*}{ Independent Variables ${ }^{2}$} & \multicolumn{4}{|c|}{ Coefficient estimate ( $t$-statistic) } \\
\hline & \multicolumn{4}{|c|}{ Dependent variables } \\
\hline & \multicolumn{2}{|c|}{ DISPERSION } & \multicolumn{2}{|c|}{$A C C U R A C Y$} \\
\hline & Model 1 & Model 2 & Model 1 & Model 2 \\
\hline & Total Disclosure & Subdivision Disclosure & Total Disclosure & Subdivision Disclosure \\
\hline CONSTANT & $\begin{array}{l}0.378 \\
(0.791)\end{array}$ & $\begin{array}{c}0.149 \\
0.317)\end{array}$ & $0.807^{*}$ & 0.672 \\
\hline SIZE & $\begin{array}{l}3.40 \mathrm{E}-02 \\
(0.798)\end{array}$ & $\begin{array}{c}0.042 \\
(0.988)\end{array}$ & $\begin{array}{l}-1.8 \mathrm{E}-03 \\
(-0.047)\end{array}$ & $\begin{array}{l}3.18 \mathrm{E}-03 \\
(0.080)\end{array}$ \\
\hline $\mathrm{LTD} / \mathrm{CE}$ & $\begin{array}{l}7.13 \mathrm{E}-04 \\
(0.904)\end{array}$ & $\begin{array}{l}5.68 \mathrm{E}-04 \\
(0.725)\end{array}$ & $\begin{array}{l}1.23 \mathrm{E}-03^{*} \\
(1.711)\end{array}$ & $\begin{array}{l}1.18 \mathrm{E}-03 \\
(1.626)\end{array}$ \\
\hline ROE & $\begin{array}{l}-4.0 \mathrm{E}-03^{*} \\
(-1.915)\end{array}$ & $\begin{array}{l}-3.06 \mathrm{E}-03 \\
(-1.456)\end{array}$ & $\begin{array}{l}-2.6 \mathrm{E}-03 \\
(-1.355)\end{array}$ & $\begin{array}{l}-2.30 \mathrm{E}-03 \\
(-1.178)\end{array}$ \\
\hline GER & $\begin{array}{l}-7.2 \mathrm{E}-02 \\
(-0.602)\end{array}$ & $\begin{array}{l}-0.107 \\
(-0.886)\end{array}$ & $\begin{array}{l}-4.3 \mathrm{E}-02 \\
(-0.390)\end{array}$ & $\begin{array}{l}-4.93 \mathrm{E}-02 \\
(-0.439)\end{array}$ \\
\hline BEL & $\begin{array}{l}-0.174 \\
(-1.419)\end{array}$ & $\begin{array}{l}-0.219 * \\
(-1.772)\end{array}$ & $\begin{array}{l}0.289^{* * *} \\
(2.597)\end{array}$ & $\begin{array}{l}0.278^{* * *} \\
(2.416)\end{array}$ \\
\hline NOEST & $\begin{array}{l}-4.2 \mathrm{E}-03 \\
(-0.574)\end{array}$ & $\begin{array}{l}-6.44 \mathrm{E}-03 \\
(-0.889)\end{array}$ & $\begin{array}{l}-3.9 \mathrm{E}-03 \\
(-0.591)\end{array}$ & $\begin{array}{l}-5.03 \mathrm{E}-03 \\
(-0.747)\end{array}$ \\
\hline $\begin{array}{l}\Delta \text { EAR } \\
\text { TD }\end{array}$ & $\begin{array}{l}-1.8 \mathrm{E}-06 \\
(-0.499) \\
-2.0 \mathrm{E}-02^{*} \\
(-1.760)\end{array}$ & $\begin{array}{l}-3.37 \mathrm{E}-06 \\
(-0.897)\end{array}$ & $\begin{array}{l}3.36 \mathrm{E}-06 \\
(1.002) \\
-2.2 \mathrm{E}-02 * * \\
(-2.064)\end{array}$ & $\begin{array}{l}2.89 \mathrm{E}-06 \\
(0.829)\end{array}$ \\
\hline $\begin{array}{l}\text { TFLD } \\
\text { THD }\end{array}$ & & $\begin{array}{c}-4.10 \mathrm{E}-02^{* * *} \\
(-2.454) \\
1.91 \mathrm{E}-02 \\
(0.818)\end{array}$ & & $\begin{array}{l}-2.59 \mathrm{E}-02 * \\
(-1.669) \\
-8.47 \mathrm{E}-03 \\
(-0.390)\end{array}$ \\
\hline
\end{tabular}




\begin{tabular}{|c|c|c|c|c|}
\hline & \multicolumn{4}{|c|}{ Coefficient estimate (t-statistic) } \\
\hline & \multicolumn{4}{|c|}{ Dependent variables } \\
\hline & \multicolumn{2}{|c|}{ DISPERSION } & \multicolumn{2}{|c|}{$A C C U R A C Y$} \\
\hline & Model 1 & Model 2 & Model 1 & Model 2 \\
\hline Independent Variables ${ }^{2}$ & Total Disclosure & Subdivision Disclosure & Total Disclosure & Subdivision Disclosur \\
\hline R-squared & 0.114 & 0.142 & 0.270 & 0.265 \\
\hline Adjusted R-squared & 0.035 & 0.055 & 0.204 & 0.190 \\
\hline \multirow[t]{2}{*}{ F-value $\mathrm{N}$} & 1.435 & 1.622 & $4.112^{* * * *}$ & $3.524 * * *$ \\
\hline & 120 & 120 & 120 & 120 \\
\hline
\end{tabular}

${ }^{1}$ The table reports OLS regression coefficients with t-statistics:

$* \mathrm{p}<.10, * \mathrm{p}<<.05, * * * \mathrm{p}<.01$.

${ }^{2} \mathrm{SIZE}=$ natural logarithm of total sales, $\mathrm{LTD} / \mathrm{CE}=$ Long-term debt/Common equity, $\mathrm{ROE}=$ Return on equity, GER $=\mathrm{Germany}, \mathrm{BEL}=\mathrm{Belgium}$, NOEST $=$ number of analysts following the company, $\triangle \mathrm{EAR}=$ absolute value of change in earnings scaled by total sales, $\mathrm{TD}=$ total disclosure, $\mathrm{TFLD}=$ total forward-looking disclosure, $\mathrm{THD}=$ total historical disclosure 
The results in Table 8 provide support for hypotheses 2 and $3 .^{6}$ The results of dispersion model 1 show that disclosure of nonfinancial information significantly decreases the dispersion in analysts' forecasts. For example, a 5-point increase in the total disclosure score decreases dispersion by 0.10 (i.e., five times the value of the regression coefficient). Return on equity appears to be a significant control variable since less profitable firms are related to higher dispersion in analysts' forecasts. A subdivision of total nonfinancial disclosure into forward looking nonfinancial information and historical nonfinancial information is presented in dispersion model 2. The results show that the disclosure of forward-looking nonfinancial information significantly decreases the dispersion of analysts' forecasts, whereas disclosure of historical nonfinancial information does not. The dispersion of analysts' forecasts for Belgian companies appears to be significantly higher compared to analysts' forecasts for Dutch companies.

The results of accuracy model 1 suggest that the disclosure of nonfinancial information significantly increases accuracy. ${ }^{7}$ Again, for example, a 5-point increase in the total disclosure score increases accuracy by 0.11 (i.e., five times the value of the regression coefficient). As a point of clarification, note that a higher reported value of accuracy indicates a lower accuracy level. Two control variables appear significant. Higher leverage is related to a lower accuracy (LTD/CE), and forecasts for Belgian companies are significantly less accurate than forecasts for Dutch companies. A subdivision of total nonfinancial disclosure into forward looking nonfinancial information and historical nonfinancial information is presented in accuracy model 2 . Similar to the dispersion results, we see that the disclosure of forward looking nonfinancial information is strongly associated with an increase in the accuracy of analysts' forecasts, while the disclosure of historical nonfinancial information does not appear to affect accuracy. The COUNTRY dummy for Belgium remains significant. In summary, the results in Table 8 provide evidence that the disclosure of forward looking nonfinancial information is strongly associated with a decrease in dispersion and an increase in accuracy, whereas the disclosure of historical nonfinancial information does not appear to affect the characteristics of analysts' earnings forecasts.

\section{Conclusions and Limitations}

In this study we attempt to improve our understanding of the factors that determine the voluntary nonfinancial disclosure choices of firms in three 
Continental European countries: Belgium, Germany and the Netherlands. We examine the degree to which companies in these three countries adhere to the nonfinancial disclosure recommendations of the Jenkins Committee, and we examine the factors that may influence the nonfinancial reporting decisions of our sample firms. We find that companies that are more internationally oriented, and/or companies that are larger, tend to provide more nonfinancial disclosures. We observe some industry effects with pharmaceutical companies providing significantly more forward looking nonfinancial information than other industries, while construction and electrical equipment provide significantly less historical financial disclosure. There are significant country effects across Belgium, Germany, and the Netherlands. This is not surprising given the different legal and institutional setting, as well as cultural and financial reporting differences among these countries. Of the six disclosure categories examined in this paper, higher levels of strategic and management disclosures are provided by Belgian and Dutch companies, by companies in the pharmaceutical industry, by companies with an international orientation, and by large companies, after controlling for the remaining independent variables.

Furthermore, our results show that voluntary disclosure of forward looking nonfinancial information is significantly associated with lower levels of dispersion and higher levels of accuracy in analysts' earnings forecasts. Disclosure of historical nonfinancial information does not appear to affect the characteristics of analysts' forecasts. Given the finding that high levels of voluntary forward looking nonfinancial information improve the prediction of a company's future performance, there is an incentive for competitors to provide highly transparent company information locally and internationally. Increased disclosure of nonfinancial information may help to level the playing field for financial analysts and investors. International corporate disclosure of both financial and nonfinancial information may improve the proper allocation of economic resources across and within capital markets.

There are limitations inherent in our study. Our sample size is small given the time-consuming process of data collection. Although every effort was made to ensure a uniform coding of company disclosure scores, this process was inevitably subjective. Also, by focusing on a single year's financial statements, we eliminate the potential confounding effects of time series variations in disclosure policies, but we limit the general applicability of our conclusions. Finally, there may be factors influencing nonfinancial disclosures for which we fail to control. For instance, a company could be foreign-owned or controlled, it could have a long-range strategic plan to 
enter foreign markets, or it may rely on foreign sources of debt. All of these potential influences could affect our results, although in general, their existence would make it more difficult to observe cultural differences.

Until nonfinancial harmonization occurs, companies can gain insights from this study about the levels of, and influences upon, nonfinancial disclosures of companies domiciled in Belgium, Germany and the Netherlands. In regard to business reporting, the FASB Status Report (May 2001) states, 'The best set of solutions will come from national and international standard setters working together. The issues are not limited to a specific country and probably do not lend themselves to an answer developed by one accounting standard setter acting in isolation.'

To improve our understanding of the value relevance of nonfinancial information for financial analysts, researchers could examine the nonfinancial items in our study to determine whether there is a relationship between available nonfinancial items in corporate annual reports and in the stock reports prepared by the analyst. With an increasing emphasis on the value of nonfinancial disclosure, a before- 1990 and after- $1990^{8}$ study might shed some light on the specific nonfinancial disclosures that aid analysts in making their stock recommendations.

With the recent relaxing of many disclosure requirements for non-US firms listed on US stock exchanges, non-US firms might find the use of nonfinancial disclosures more satisfactory than extensive financial disclosures (which can be quite difficult to measure and understand). Saudagaran and Biddle (1995) note that countries with extensive and costly accounting disclosures and pre-registration requirements discourage listings of foreign firms. If nonfinancial disclosures become harmonized, researchers can eventually track whether nonfinancial disclosures are helpful in increasing cross-border listings.

\section{Appendix: Disclosure Scoring System}

\section{Forward-Looking Nonfinancial Information}

Environment Around the Company

Ability of new companies to enter the industry

Ability of substitute products or services to displace those of reporting company

Company's relationships with others

Competitors and their positions within the industry

Changes in markets, competition, or technology

Competitive advantages and disadvantages (identity, source, and sustainability)

Description of company's industry structure

Growth or shrinkage in market share

Information about economy, company's industry, and company itself 
Intensity of competition in the industry

Recent changes in environment; nature and timing of company's response

Regulation and legislation affecting segment

\section{Strategy and Management}

Consistency of strategy with external trends and with managerial approach

Enabling infrastructures

a) organizational structure, b) business strategy,

c) management philosophy, d) employee incentives

Financial information by management responsibility

Goals for return on assets, equity, and capitalization ratio

Identity and background of directors and management

Identity and description of management incentive plans

Identity of major shareholders, all shares owned, and by directors, management, \& employees

Information about compensation committee interlocks \& insider participation in decisions

Major goals, strategy, and factors that are critical to successfully implementing strategies

Methods of conducting the business

Mission, broad objectives, and strategy to achieve broad objectives

Nature of disagreements with prior directors, bankers, independent auditors, and lead counsel

Need to know the major segments by which management operates the company

Types and amounts of director/management compensation and methods used to compute

\section{Company Trends}

Beneficial or detrimental circumstances in which the company is involved and that may

cause increase or decrease cash flows in the future

Changes in financial position and why

Company's financial flexibility, changes and why (identify sources of liquidity)

Explanation of relationships and changes among the data

Qualitative forward-looking information

a) Forecasts, b) Prospective Information, c) Plans and Objectives

\section{Historical Nonfinancial Information}

Environment of the Company

Description of business and industry structure

Employee involvement \& fulfillment-rate of change in it

General development of the business-major events in last 5 years

Number of employees, average compensation of employees

Related party identity and description of relationship

Scope and description of the business and related properties

Seasonality and cyclicality

\section{Production}

Amount and quality of key resources and related suppliers

Definition of industry (or other segment)

Description and duration of important patents, trademarks, etc.

Description of nature of operations and current vulnerability due to concentrations

Description of principal products/services

Growth in units sold or average prices of units sold

Information about geographic concentrations in the production base

Information about the change in the nature of the warranty for a product

Innovation 
Large changes in the proportion of materials purchased from the one or two largest suppliers

Nonfinancial historical business information (often about ten years) - backlog figures

Recent process, product, or service innovations; sources and consequences

Relative bargaining power of resource providers

Resource provider satisfaction

Timeliness to perform key activities (production, delivery, developing new products)

Trends in sales, sales prices, unit costs and reasons why

Volume and prices of materials consumed

Where products are produced and where they are delivered

\section{Customers}

Information about geographic concentrations in the sales base of a company Information about technological and regulatory change that may affect the market Information from a marketing, merchandising, and distribution point of view Large increases or decreases in the proportion of products or services sold to largest customers

Major contractual relationships

Market acceptance-changes in prices, volumes, and products, and why

Market penetration and quality

Measures of customer satisfaction

Relative bargaining power of customers

\section{Notes}

1. The Adhikari et al. (1998) study examined the information needs of financial analysts across cultural categories. The ABT researchers found differences across cultural categories in the perceived need for disclosure of factors which they term 'nonfinancial', 'control', and 'annual report'. They also reported the relative rankings of the factors included in their survey. After audited financial statements, the majority of items in the top third of the 44-item list comprise nonfinancial information of a 'forward looking' or predictive nature. Historical information items were ranked primarily at the bottom of the list. Most of the items included in the ABT survey are similar to those indicated as desirable by analysts in the Jenkins Committee report.

2. On average, the use of one-month ahead forecasts will make the analysts' forecasting ability appear to be very good. This should make it more difficult for us to detect crosssectional differences in forecasting accuracy, and hence, it should bias against our finding any significant cross-country effects.

3. As a robustness test we re-scale these disclosure indices by giving a $1 / 2$ weight to each of the two categories (forward-looking and historical) and a $1 / 3$ weight to each of the three categories within each index, thus, equally weighting each category. The results (not reported) are not substantively different from those reported in Tables 6 and 7.

4. A low reported value corresponds with high accuracy.

5. Note that analyzing the data with OLS give substantively similar results. Hence, the results are not sensitive to the estimation technique.

6. Given the strong correlation between total sales and the number of analysts following a company, we re-run the regression without the number of analysts variable. The results remain unchanged.

7. Outliers for analyst forecast data were deleted; in total, six observations.

8. The year 1990 is approximately the time during which the AICPA and the AIMR (financial analysts) were involved in their detailed discussions about types of useful information for company analysis. 


\section{References}

Adhikari, A. and R.H. Tondkar, "Environmental Factors Influencing Accounting Disclosure Requirements of Global Exchanges," Journal of International Financial Management and Accounting 4 (1992), pp. 75-105.

Adhikari, A., L. Betancourt and R.H. Tondkar, "The Influence of Culture and Equity Market Development on Financial Analysts' Perceptions of Disclosure Items in Listing Prospectuses," Advances in International Accounting 11 (1998), pp. 1-22.

AICPA, Database of Materials on Users Needs for Information (New York: American Institute of Certified Public Accountants, Inc., 1994a).

AICPA, Improving Business Reporting A Customer Focus (New York: American Institute of Certified Public Accountants, Inc., (1994b)).

Ahmed, K. and J. Courtis, "Associations between Corporate Characteristics and Disclosure Levels in Annual Reports: a Meta-Analysis," British Accounting Review 31 (1999), pp. 35-61.

AIMR Corporate Information Committee Report (Charlottesville: Association for Investment Management and Research, (1992)).

Baginski, S. and J. Hassell, "The Market Interpretation of Management Earnings Forecasts as a Predictor of Subsequent Financial Analyst Forecast Revision," The Accounting Review 65 (1990), pp. 175-190.

Barron, O.E. and P.S. Stuerke, "Dispersion in Analysts' Earnings Forecasts as a Measure of Uncertainty," Journal of Accounting, Auditing and Finance 13 (1998), pp. 245-270.

Barron, O.E., O.C. Kile and T.B. O'Keefe, "MD\&A Quality as Measured By the SEC and Analysts' Earnings Forecasts," Contemporary Accounting Research 16 (1999), pp. $75-109$.

Barry, C.B. and S.J. Brown, "Differential Information and the Small Firm Effect," Journal of Financial Economics 13 (1984), pp. 283-295.

Barry, C.B. and S.J. Brown, "Differential Information and Security Market Equilibrium," Journal of Financial and Quantitative Analysis 20 (1985), pp. 407-422.

Barry, C.B. and S.J. Brown, "Limited Information as a Source of Risk," Journal of Portfolio Management 12 (1986), pp. 283-295.

Basu, S. and L. Hwang, "International Variation in Accounting Measurement Rules and Analyst Earnings Forecast Errors," Journal of Business Finance \& Accounting 25 (Jan 1998), pp. 1207-1247.

Bhushan, R., "'Collection of Information about Publicly Traded Firms: Theory and Evidence," Journal of Accounting and Economics 11 (1989), pp. 183-207.

Chang, J.J., T. Khanna and K.G. Palepu, "Analyst activity around the world”, Working paper (University of Pennsylvania and Harvard University, 2000).

Choi, F.D.S., "Financial Disclosure and Entry to the European Capital Market," Journal of Accounting Research 11 (1973), pp. 159-175.

Diamond, D., "Optimal Release of Information by Firms," Journal of Finance 40 (1985), pp. 1071-1094.

Diamond, D. and R.E. Verrecchia, "Disclosure, Liquidity and the Cost of Capital," Journal of Finance 66 (1991), pp. 1325-1355.

Easley, D. and M. O'Hara, "Information and the cost of capital", Working paper (Cornell University, 2000).

Eccles, R.G., R.H. Herz, E.M. Keegan and D.M.H. Phillips, The ValueReporting ${ }^{T M}$ Revolution (Wiley, (2001).

FASB Business and Financial Reporting, Challenges from the New Economy. Financial Accounting Series (FASB, May 2001). 
Gray, S., "Towards a Theory of Cultural Influence on the Development of Accounting Systems Internationally," Abacus 24 (1988), pp. 1-15.

Gray, S. and H.M. Vint, "The impact of culture on accounting disclosures: some international evidence", Working paper (University of Warwick, 1994).

Harris, D., "The Impact of U.S. Tax Law Revision on Multinational Corporations Capital Location and Income Shifting Decisions," Journal of Accounting Research 31(Supplement) (1993), pp. 111-140.

Harris, M. and A. Raviv, "Differences in Opinion make a Horse Race," Review of Financial Studies 6 (1993), pp. 473-494.

Healy, P.M. and K.G. Palepu, "Voluntary corporate disclosure: Who, what, and why?", Working paper (MIT, 1994).

Healy, P.M. and K.G. Palepu, "Information Asymmetry, Corporate Disclosure, and the Capital Markets: A review of the Empirical Disclosure Literature," Journal of Accounting and Economics 31 (2001), pp. 405-440.

Hofstede, G., Culture's Consequences: International Differences in Work-Related Values (Beverly Hills: Sage, (1980)).

Hope, Ole-Kristian, "The relation between accounting and institutional factors and analysts' forecasts: an international study", Working Paper (University of Toronto 2001).

Hope, Ole-Kristian, "Disclosure practices, enforcement of accounting standards and analysts' forecast accuracy: An international study", Journal of Accounting Research, forthcoming (May 2003).

Hussein, Mohamed E., "A Comparative Study of Cultural Influences on Financial Reporting in the U.S. and the Netherlands," Inernational Journal of Accounting 31 (1996), pp. 95-120.

Jennings, R., "Unsystematic Security Price Movements, Managerial Earnings Forecasts, and Revisions in Consensus Analyst Earnings Forecasts," Journal of Accounting Research 25 (1987), pp. 90-110.

Jovanovic, B., "Truthful Disclosure of Information,” Bell Journal of Economics 13 (1982), pp. 36-44.

Kim, O. and R.E. Verrecchia, "Market Liquidity and Volume Around Earnings Announcements," Journal of Accounting and Economics 17 (1994), pp. 41-68.

Klassen, K., M. Lang and M. Wolfson, "Geographic Income Shifting by Multinational Corporations in Response to Tax Rate Changes," Journal of Accounting Research 31(Supplement) (1993), pp. 141-173.

Lang, M.H. and R.J Lundholm, "Corporate Disclosure Policy and Analyst Behavior," Accounting Review 71 (1996), pp. 467-492.

La Porta, R., F. Lopez-de-Silanes, A. Schleifer and R. Vishny, "Legal Determinants of External Finance," Journal of Finance 52 (1997), pp. 1131-1150.

La Porta, R., F. Lopez-de-Silanes, A. Schleifer and R. Vishny, "Law and Finance," Journal of Political Economy 106 (1998), pp. 1131-1150.

Leuz, C., D. Nanda and P.D. Wysocki, "Investor protection and earnings management: an international comparison", Working paper (University of Pennsylvania, Duke University and MIT Sloan School of Management, 2002).

Nichols, D., The Handbook of Investor Relations (Homewood, IL: Dow Jones-Irwin, 1989).

Perera, M., "Towards a Framework to Analyze the Impact of Culture on Accounting," International Journal of Accounting 24 (1989), pp. 42-56.

Radebaugh, L.H. and S.J. Gray, International Accounting and Multinational Enterprise, fourth edition (Wiley, 1993). 
Robb, S., L. Single and M. Zarseski, "Nonfinancial Disclosures Across Anglo-American Countries," Journal of International Accounting, Auditing and Taxation 10 (2001), pp. 71-84.

Saudagaran, S.M. and G.C. Biddle, "Foreign listing location: a study of MNCs and stock exchanges in eight countries," Journal of International Business Studies 26 (1995), pp. 319-341.

Saudagaran, S.M. and G.K. Meek, "A Review of Research on the Relationship between International Capital Markets and Financial Reporting by Multinational Firms," Journal of Accounting Literature 16 (1997), pp. 127-159.

Schipper, K., “Analysts' forecasts,” Accounting Horizons 4 (1991), pp. 105-121.

Securities and Exchange Commission (SEC) International Accounting Standards, February 16 (2000), Release nos. 33-7801, 34-42430; International Series Release No. 1215; File No. S7-04-00.

Verrecchia, R.E., "Discretionary Disclosure," Journal of Accounting and Economics 5 (1983), pp. 179-194.

Waymire, G., "Additional Evidence on the Accuracy of Analyst Forecasts Before and After Voluntary Management Earnings Forecasts," The Accounting Review 59 (1986), pp. 129-142.

Zarzeski, M., "Spontaneous Harmonization Effects of Culture and Market Forces on Accounting Disclosure Practices," Accounting Horizons 10 (1996), pp. 18-37. 
Copyright $\odot 2003$ EBSCO Publishing 